\title{
UNIVERSITYOF
}

FORWARD

THINKING

WESTMINSTER用

WestminsterResearch

http://www.westminster.ac.uk/westminsterresearch

Engaged Disengagement: Reframing as Feminist Critique in

Vanessa Place's Tragodía

Colby, G.

This is an author's accepted manuscript of an article accepted published in Textual Practice, DOI:10.1080/0950236X.2016.1153514, Published online: 26 Apr 2016

The final definitive version is available online at:

http://dx.doi.org/10.1080/0950236X.2016.1153514

The WestminsterResearch online digital archive at the University of Westminster aims to make the research output of the University available to a wider audience. Copyright and Moral Rights remain with the authors and/or copyright owners.

Whilst further distribution of specific materials from within this archive is forbidden, you may freely distribute the URL of WestminsterResearch: ((http://westminsterresearch.wmin.ac.uk/)).

In case of abuse or copyright appearing without permission e-mail repository@westminster.ac.uk 


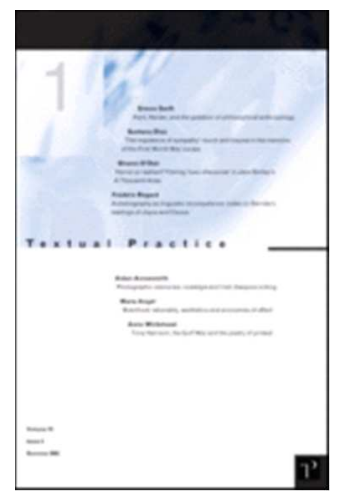

\section{Engaged Disengagement: Reframing as Feminist Critique in Vanessa Place's Tragodía}

\begin{tabular}{|r|l|}
\hline Journal: & Textual Practice \\
\hline Manuscript ID: & RTPR-2015-0017 \\
\hline Manuscript Type: & Original Article \\
\hline Keywords: & conceptual writing, Vanessa Place, feminism, allegory \\
\hline \multicolumn{2}{|}{} \\
\hline
\end{tabular}

SCHOLARONE $^{\text {Im }}$

Manuscripts

URL: http://mc.manuscriptcentral.com/rtpr Email: pboxallpeter@googlemail.com 


\section{Engaged Disengagement: Reframing as Feminist Critique in Vanessa Place's Tragodía}

Vanessa Place's three-volume series of conceptual writing, Tragodia (2011) is part of the body of conceptual poetry that has emerged in the U.S in the twenty-first century. In the preface to her recent study unoriginal genius: poetry by other means in the new century (2010), Marjorie Perloff examines the innovation in contemporary poetry precipitated by the unconstrained conditions engendered by the Internet. Perloff observes that during this phase of experimentation at the turn of the century, poets became interested not in their own linguistic creations but 'how already existing words and sentences are framed, recycled, appropriated, cited, submitted to rules, visualized or sounded. ${ }^{1}$ Alongside the works of Kenneth Goldsmith, Craig Dworkin, and Rob Fitterman, Place's Tragodia is paradigmatic of that which Perloff articulates as the 'new citational and often constraint bound poetry", and the body of work Goldsmith, following Perloff, terms 'uncreative writing. ${ }^{3}$ A considered enquiry into certain concepts and conceptual apparatuses such as allegory, hermeneutics, and the performative use of indifference in conceptual writing generates productive insights into new narrative conditions produced by Place's conceptual writing. This essay positions Place's Tragodía as an instance of reframing as contemporary feminist cultural critique. Through appropriation, Tragodia creates a field of contextual resistance to the oppression of the personhood of the victims of sexual crimes enacted in legal discourse.

Place's Tragodía is a contemporary work of détournement. In an attempt to define a contemporary form of détournement, Place makes reference to Patrick Geaney's quoting of Debord in his essay 'Insinuation: Détournement as Gendered Repetition.' Place remarks that Debord is misquoting Baudelaire in his articulation of détournement, as that which occurs when poets 'enter into enemy territory and repeat the locutions that they undermine. In this repetition, poets burrow into language, but they, too, are dug into, penetrated by the very language that they want to overcome and keep at a distance. ${ }^{4}$ The conceptual poet, scholar and performance artist, Caroline Bergvall, understands this penetration of the conceptual writer by the language the writer's work seeks to critique to be one of the overarching challenges that contemporary women writers meet in their conceptual practices. For Bergvall, the difficulty resides in the poet's struggle to refrain from producing a mode of poetics that is a mode of production fetishism. Put simply, Bergvall asks 'How does one put a text together that depersonalizes, that disengages from personalized modes, yet manages to engage with

\footnotetext{
${ }^{1}$ Marjorie Perloff, unoriginal genius: poetry by other means in a new age, xi.

${ }^{2}$ Perloff, unoriginal genius, xi.

${ }^{3}$ Kenneth Goldsmith, Uncreative Writing (New York: Columbia University Press, 2011).

${ }^{4}$ Vanessa Place, 'Afterword' to I'll Drown My Book: Conceptual Writing by Women, 446.
} 
processes of personification and identification?' ${ }^{5}$ In Bergvall's view it is a question of the conceptual text's ability to simultaneously accommodate distance and intimacy:

If literature is perceived as a mediating apparatus, a symbolic representation that highlights features of social engineering as much as of individual motivation, how does one create textual works where the authorial hold over the text is somehow distanced, perhaps neutralized, yet where the structural impact of experience, of living, of loving, of knowing, of reading are in fact recognized. ${ }^{6}$

Responding to the work of 62 women writers in the anthology I'll Drown My Book: Conceptual Writing By Women (2012), Bergvall delineates two pathways that the writers take as means to circumvent production fetishism: the 'road' and the 'route' of 'engaged disengagement.' The 'road' of engaged disengagement involves 'A willingness to constantly, relentlessly examine the means of one's own intentionality, positioning, assumptions, expectations.' The 'route' of engaged disengagement entails 'A willingness to accept the laughable obsessiveness of one's intent in the face of the all-corrupting consumption machine [...] It is dead serious playfulness, interdependence, networked provocation, and conscious games. ${ }^{7}$ Place's Tragodia harbours both the road and the route of engaged disengagement. In the following analysis Place's conceptual practice will be shown to expose and interrogate the questions of 'intentionality, positioning, assumptions, expectations' that her texts raise. Place's work also generates debates over the work's complicity with the institutional structures of the Law that it seeks to critique, and it is precisely the 'networked provocation' for which the work is a catalyst, that is a site of resistance in the text.

By day, Place is an appellate criminal defense attorney in the State of California. Her poetic practice involves acts of pure appropriation. ${ }^{8}$ The first volume of Tragodía, entitled Statement of Facts, takes the transcriptions of appellate briefs and the legal documents of violent sexual criminal acts and resituates them onto the literary page through an act of reframing. As Goldsmith has observed, Place's only alteration of the documents is her

\footnotetext{
${ }^{5}$ Caroline Bergvall, 'The Conceptual Twist', Foreword to I'll Drown My Book: Conceptual Writing By Women, edited by Caroline Bergvall, Laynie Browne, Teresa Carmody, and Vanessa Place (Los Angeles: Les Figues Press, 2012), p. 21.

${ }^{6}$ Ibid.

7 Ibid.

${ }^{8}$ Place has carried out other acts of pure appropriation. Her recent work Radio Breaks, Full Audio Transcripts is comprised of the communications between the Federal Aviation Administration, North American Aerospace Defense Command, and American Airlines that took place on September 11, 2001.
} 
removal of the serif font demanded by the legal profession. ${ }^{9}$ Tragodia is a discursive construction, a collage of victims' and rapists' depositions, testimonies, and police reports. Goldsmith also points to the fact that all of the legal documents that Place appropriates are freely available from public records archives. ${ }^{10}$ Yet as both Goldsmith and Moschovakis have noted, Place, as attorney, has also written the original documents. ${ }^{11}$ Place's key concern in this work is the status of personhood as it is intimated or enacted by legal discourse. Crucially, the rape victims' testimonies are narrated to representatives of the law, and as a consequence, their discourse is perpetually overlaid in the ideological interpretation of the legal narratives. This essay pays close attention to the theatrical dimension of Place's conceptual writing, as a means to explore the condition of personhood in the narratives but also to interrogate the way in which a tension between framing and telling in legal discourse is registered in Place's work. Building on Goldsmith's desire to 'map [...] territories, define terminologies, and create contexts ${ }^{12}$ in which conceptual writing can be positioned and discussed, this essay explores both the potential of conceptual writing to embody a mode of resistance to trauma, and to offer a particular contextual encounter between contemporary feminist poetics and the law.

It is my contention that Tragodia does not represent trauma but rather generates trauma through a poetic practice that has a bipartite structure: conceptual writing (allegory) and Place's performance of the narratives. Place's performance is an ancillary act of reframing that raises the question of what might be at stake in the performative use of indifference. The linguistic apparatus of the legal case studies echoes the psychoanalytic case studies of Freud and Breuer at the turn of the twentieth century, in which the patient's discourse is narrated, written, and thereby overlaid by the discourse of the psychoanalyst. This enquiry seeks to ascertain if traces of subjectivity can be found in the legal narratives, or, if the deformation of the speech acts of the subjects in legal discourse has erased all subjectivity. In such an analysis both the question of the extent of the depersonalization of the victims of rape in legal discourse through the deformation of the their language and speech acts arises, as well as the issue of whether Place's conceptual writing, through the act of reframing, is able to create new narrative conditions in which the resistance and constitution of the subject is manifested in the text.

\footnotetext{
${ }^{9}$ Goldsmith, Uncreative Writing, 104. In his analysis, Goldsmith cites Place's terms for such textual requirements: "those little epaulets of authority."

${ }^{10}$ Ibid, 102.

${ }^{11}$ Ibid. Goldsmith is citing Anna Moschovakis, 'Poetics of Guilt', American Book Review, Vol. 32. Number 4, May/June 2011, 9.

12 Goldsmith, Uncreative Writing, 11.
} 
Allegory

Place makes a number of theoretical interventions on conceptual writing practices in her libretto-manifesto Notes on Conceptualisms (2010), co-authored with Robert Fitterman. In the Foreword to this short work, Fitterman gestures towards an understanding of conceptual writing in the contemporary period. He states that he, Place, and Anna Moschovakis, use the term conceptual writing in the broadest sense 'so that it intersects with other terms such as: allegory, appropriation, piracy, flarf, identity, theft, sampling, constraint and others. ${ }^{13}$ The opening of the manifesto reinforces the homologous relationship between the authors' works and the first of these terms: 'Conceptual writing is allegorical writing. ${ }^{14}$ This analogy is continually reiterated and explored throughout the manifesto. For Goldsmith, Fitterman, and Place, Walter Benjamin is the notable precursor of conceptual writing in terms of both practice and theory. Goldsmith considers The Arcades Project (1927-1940) to be 'the greatest book of uncreative writing ${ }^{15}$ and a clear antecedent to works of pure appropriation in the twenty-first century. For Place and Fitterman, it is Benjamin's chapter on allegory and trauerspiel in The Origins of German Tragic Drama (1928) that provides a foundation for theorizing allegory today.

According to Fitterman and Place, contemporary allegorical writing is comprised of a pre-text and a post-text. The first of these components is explained in an early definition:

The standard features of allegory include extended metaphor, personification, parallel meanings, and narrative. Simple allegories use simple parallelisms, complex ones more profound. Other meanings exist in the allegorical "pre-text," the cultural conditions within which allegory is created. Allegorical writing is a writing of its time, saying slant what cannot be said directly, usually because of overtly repressive political regimes or the sacred nature of the message. In this sense the allegory is dependent on its reader for completion (though it usually has a transparent or literal surface). ${ }^{16}$

This explanation asserts the reader's role in the construction of allegory, a key aspect of Place's work when considering her performance. The structure of allegory referenced here has a concrete example in Tragodia 1: Statement of Facts, which is comprised of pre-textual

\footnotetext{
${ }^{13}$ Rob Fitterman and Vanessa Place, Notes on Conceptualisms (Brooklyn: Ugly Duckling Press, 2010), 10.

${ }^{14}$ Ibid, 13.

15 Goldsmith, Uncreative Writing, 109.

${ }^{16}$ Fitterman and Place, Notes on Conceptualisms, 13.
} 
materials, being a collage of transcripts of prosecution cases, transcripts of defense cases, details of medical examinations/sexual assault examinations, expert testimonies, rebuttals and police reports. Read in terms of the features of allegory set out in Note on Conceptualisms, the law exists in the allegorical pre-textual construct of Place's work as manifesting certain 'cultural conditions.' Statement of Facts is the "post-text", 'the document necessarily created by the pre-text, though post-text may refer to a primary text used in hybrid as a secondary text. ${ }^{17}$ It is the conceptual procedure of appropriation that enacts the transformation from pretext to post-text. Place and Fitterman state: 'To the degree conceptual writing depends upon its extra-textual feature for its narration, it exists, like the readymade - as a radical reframing of the world. ${ }^{18}$

The legal documents that form Statement of Facts have been detached from their bureaucratic habitation and resituated onto the literary page. Context is a primary form of signification in the conceptual work. In her Afterword to the anthology, I'll Drown My Book, Place remarks: 'in the way of positive or negative space, conceptualism is [...] writing in which the context is the primary locus of meaning-making. ${ }^{19}$ In content, the materials of Tragodia remain identical to their original state, when they were housed within the parameters of the legal institution. As literary texts however, the documents no longer perform the functions for which they were written. For instance, the depositions, formal statements used as evidence outside court, do not operate as evidence in a trial when situated in a literary context. Rebuttals, often placed after the prosecution and defense cases function in the literary text as an addendum, or an Afterword that serves to keep the narrative open and in question, rather than fulfilling the legal purpose of refutation and contradiction. Conceptual writing mediates, Fitterman and Place observe, 'between the written object [...] and the meaning of the object by framing the writing as a figural object to be narrated. ${ }^{20}$ Read as literary texts, the legal statements become narratives. Place's act of reframing foregrounds language and brings to light the theatricality of the discursive constructions and the oppressive nature of the ideological discourse within which the victims' voices are subsumed. Victims narrate their traumas to figures of the law and these figures then relate the testimonies and frame these organic narratives in the institutional language of the law. Within the new literary framework of Statement of Facts the tension between framing and telling becomes apparent. It is this cohabitation of framing and telling that is the site of Place's institutional critique.

\footnotetext{
${ }^{17}$ Ibid., 21.

${ }^{18}$ Ibid., 39.

${ }^{19}$ Place, 'Afterword' to I'll Drown My Book: Conceptual Writing by Women, 446.

${ }^{20}$ Fitterman and Place, Notes on Conceptualisms, 16.
} 
The act of reframing then transforms the pre-text into the post-text. The features of allegory are significant here and illuminate the operations at work in the transfiguration of the text. For Fitterman and Place, in allegorical writing, "prosody shuttles between a micro attention to language and macro strategies of language i.e the use of source materials in reframing or mixing. ${ }^{21}$ Macro strategies of language are found in Statement of Facts at the structural level of appropriation. The title Tragodía, playing on the Ancient Greek word for tragedy (tragōidia), invokes the work as a contemporary tragic drama. The thirty-three sections in the first volume, each titled 'Statement of Facts', are constituted by the legal documents lifted by Place and resituated onto the literary page. Each section is a collage, the heterogeneous nature of which is significant to the work's allegorical structure. In contrast to traditional allegorical writing, Fitterman and Place assert, conceptual writing must have the capacity to embody 'unintended pre- or post- textual associations.' This manifestation 'abrogates allegory's (false) simulation of mastery, while remaining faithful to allegory's (profound) interruption of correspondences.' 'Allegory', Fitterman and Place claim, 'breaks mimesis via its constellatory features.' ${ }^{22}$ The large-scale conceptual apparatus of appropriation and collage in Tragodia annul the legal text's claim to mastery and frame the smaller scale conceptual gestures that make language the most prominent feature of the writing. An instance of this occurs at the outset of each volume in the table of contents. The lists of the thirty-three identical titles of the cases, 'Statements of Facts', 'Statement of the Case', and 'Argument', acquire a density in their repetition and indicate the constraint and indifference of the ideological discourse of the legal system. This oppression, conveyed in the reiteration of the functional titles, prefaces the eclipsing of the victims by the language of the law, a pervading aspect of the texts that becomes apparent through reframing. A similar pattern occurs in the second volume, Statement of the Case, in the lists of the counts upon which the appellant in the case has been convicted. One extensive list details sixty-four counts upon which the appellant was found guilty as charged. Each count is detailed along with the details of the sentence:

count 1 - one-third the midterm of four years, doubled as a second strike, run consecutively; count 2 - fifty years to life, pursuant to section 667.61, subdivision (d)(4); count 3 - the upper term of 8 years, doubled as a second strike, run consecutively; count 4 - the upper term of 8 years, doubled as a second strike, run consecutively;

\footnotetext{
${ }^{21}$ Ibid.

${ }^{22}$ Ibid., 21.
}

URL: http://mc.manuscriptcentral.com/rtpr Email: pboxallpeter@googlemail.com 6 
count 5 - one-third the midterm of four years, doubled as a second strike, run consecutively; ${ }^{23}$

The sentence preceding the list states that the appellant in this case was sentenced to 1,040 years and an additional ten life times. In a literary context, the repetition of sentences (in both the legal and literary meanings of the word) has the effect of linguistic accumulation that reflects both the excessive violence of the crime and the illogicality of the sentence passed. The appellant will likely only ever be able to serve one eighth, at the very most, of the total number of years to which he has been sentenced. In a literary context then the numbers become ideogrammatic of the violence inflicted by the appellant, crimes documented in the previous volume, Statement of Facts. Elsewhere, Place has pointed to the difference between mimesis and metamorphosis with regards to conceptual writing. ${ }^{24}$ In this instance of contextual metamorphosis cited above, the transformation from the legal object to the figural object is evident. Parallel meanings characteristic of allegory abound (the inflected 'sentence'). Words lose their legal meanings, 'count' becomes an ironic imperative, and the final sentence: 'This appeal from a final judgment of conviction is timely' ${ }^{25}$ acquires a sardonic tone.

Each section of the third volume, Argument, the most manifold part of Tragodia in terms of textual collage, opens with an indented statement in block capitals, set apart from the proceeding text:

\author{
ARGUMENT \\ APPELLANT'S CONVICTIONS ON THOSE COUNTS INVOLVING RIKKI E. MUST \\ BE REVERSED AS THE WITNESS'S FACIAL COVERING \\ DURING THE TRIAL VIOLATED APPELLANT'S SIXTH AMENDMENT RIGHT \\ TO CONFRONTATION AND TO A FAIR TRIAL
}

As noted, Rikki E. testified wearing large sunglasses and a headscarf. Defense counsel repeatedly objected to the disguise, noting that even after the scarf

\footnotetext{
${ }^{23}$ Place, Tragodía 2: Statement of the Case (Los Angeles: Blanc Press, 2011), 44.

${ }^{24}$ Place, 'Afterword' to I'll Drown My Book, 445.

25 Place, Tragodia 2: Statement of the Case, 47.
} 
was removed during testimony, Rikki's eyes and the top portion of her face were not visible through the dark glasses. (RT 4:665, 4:768-770, 5:903-904, 7:115) ${ }^{26}$

The block capitals draw attention to the law's imperative that Rikki. E be exposed to her alleged attacker. Through the typographical design of the text, as with the 'counts' in Statement of the Case, the absurdity of the proposition is foregrounded, the appellant could be released from the charge of a violent sexual assault based on the victim's wish not to be subjected to his gaze. Such conceptual gestures function at once to devalue the texts as instruments of the law and to recast their features in light of the linguistic edifice of which they are a part. As a result of the work of the allegorist, 'the work is invented via its adoption. ${ }^{27}$

In terms of the contextual transformation from pre-text to post-text, Tragodia operates at both the macro and micro levels, at the macro level of the allegorical structure of the work, and Place's conceptual act of reframing, to the micro level of drawing attention to the inflections and subversions generated by restaging language. Allegory renders the text in the manner that Fitterman and Place suggest: 'Pure conceptualism negates the need for reading in the traditional textual sense - one does not need to "read" the work as much as think about the idea of the work. ${ }^{28}$ The reinvention of the work is an example of that which Place and Fitterman understand to be 're-iteration' or 're-cognition. ${ }^{29}$ At the micro level of the language and the content of the narratives, the new literary context reveals the oppression of the victim's speech acts, as well as the potential resistance of the conceptual text. The following textual analysis, that explores corollary issues of the question of hermeneutics and the performative use of indifference in Place's conceptual writing, seeks to determine if agency and subjectivity can be found or felt in the discursive construction of Tragodia, or if the deformation of the victims speech acts by the law has erased these elements completely.

\section{The Question of Interpretation}

Reading Tragodia as a feminist act of reframing brings to light the nature of interpretation as it is found in Place's conceptual text. In Tragodia, interpretation is the opposite of hermeneutics. The law's nomothetic rendering of the victims' discourse reifies, systematizes, and consequently deforms the narratives - it is this deformation that is the work of interpretation. By contrast, as Place remarks, the conceptual text is precisely 'writing that

\footnotetext{
${ }^{26}$ Place, Tragodía 3: Argument (Los Angeles: Blanc Press, 2011), 143.

${ }^{27}$ Fitterman and Place, Notes on Conceptualisms, 26.

${ }^{28}$ Ibid., 25.

${ }^{29}$ Ibid., 26.
} 
does not self-interpret, is not self-reflexive, at least not on the page. ${ }^{30}$ Place's contextual transference from the law to the literary brings legal discourse under linguistic scrutiny and exposes the violence of the interpretative logic at work in the legal text. Foregrounding linguistic structures, the post-text brings to light the discursive formations of the legal documents. In Statement of Facts, the victims in the rape cases are interpellated by their names and yet their voices and testimonies are eclipsed through the structures of narration. The accused remain anonymous, shielded as linguistic placeholders by ideological discourse, interpellated simply as 'appellant' or 'suspect'. The following excerpt is just one example:

Appellant came to the bed and raped Arianna; either Suspect 1 or 4 was standing by the bed. Miranda was screaming in the bathroom. Suspect 3 , standing by the wall, said Miranda had to shut up; appellant gave the gun to Suspect 3, who pointed it at Miranda, who dropped to her knees, Suspect 3 put the gun to Miranda's head and pulled the trigger. There was no shot, and the men laughed and called Suspect 3 "Psycho." Suspect 3 told Miranda that it was her lucky day: there were two bullets in the gun. (RT 4:1835-1839, $4: 2143-2145)^{31}$

The coexistence of framing and telling throws the text into ambivalence. On the one hand, Arianna and Miranda are named, identified, and thus given a degree of subjectivity that the appellant and the suspects are not. Such interpellation is held in uneasy conflict with the reduction of their traumatic experience to a factual account, an act that linguistically shields the perpetrators through the omission of the victim's subjective renditions of the events. Through reframing, Tragodia stages the narratives and, in doing so, embodies a dialectical tension between the victims' narrativization of the traumatic experiences of rape, bodily harm, and sexual abuse and the dissemination of these narratives in the ideological discourse of the legal system. The following is an excerpt from a Prosecution Case that details the rape case of Tye, a girl who was ten years old at the time of the trial; the appellant is her great uncle:

Tye was crying during the assault examination. She told the attending deputy that the day before she had been watching TV on the floor of Uncle Jackie's apartment when Uncle Jackie told his girlfriend Vondra to take a shower. After Vondra left, he told Tye she could lie on the bed. He lay down next to

\footnotetext{
${ }^{30}$ Place, 'Afterword' to I'll Drown My Book, 446.

${ }^{31}$ Vanessa Place, Tragodía I: Statement of Facts (Los Angeles: Blanc Press, 2010), 203.
} 
her, pulled down his pants, and put his "pee-pee" in her mouth. He put his hands over Tye's mouth when she started to scream. After taking his penis out of her mouth, appellant put two fingers in her "coo-coo," then put his penis in her vagina. Tye tried to push appellant away, kneed him in the groin and bit his neck. Tye described appellant's penis as getting bigger and described him ejaculating. Appellant left the bed, and Tye called her mother. (RT 4: 12641270, 4:1294-1295) $)^{32}$

The statements fuse the victim's discourse with that of the law. Tye's voice and distress are overruled by the objective narration that deforms Tye's traumatic experience of sexual abuse. In the legal narration a third party narrates the sufferer's testimony. The legal and medical terminology (the latter more pronounced at other points in Statement of Facts that document the medical reports of the victims' injuries) lacks affect and inflicts violence; there are no modifiers for anatomical words such as 'penis', 'ejaculating' and 'vagina' in the legal account. By comparison, the child's linguistic register that signals her prepubescence modifies the experience linguistically, she uses the euphemism "coo-coo" in place of vagina and "pee-pee" to substitute "penis". The unmediated medical and legal language relating an instrumental understanding of the victim's trauma conflicts with the language of the sufferer. The child's unadulterated linguistic register is adulterated by the law through the act of interpretation. The abuse of Tye appears in this passage to be emphasized by the deformation of her language by the figures of the law. In short, the act of interpretation in Statement of Facts is an act of deformation of the subjects' speech acts.

\section{The Violence of Indifference}

In Place's work, the impersonal constructions of the victims' narratives within legal discourse manifest a violence of indifference at the level of institutional language, this is apparent in the analysis of Tye's narrative discussed above. The phenomenology of affect is essential to Tragodia. It could be assumed that the original statements related to the figures of the law embody affect. However, the textual deformation of the speech acts by the figures of the law to whom they are related precludes such an assumption, as the falsification of the narratives through institutional transmission into statements of facts renders any such assertion mere conjecture. In this way, the interpretation of the victim's narratives by the law delegitimizes any attempt at a hermeneutical enquiry into the text. It is worth noting here that for scholars in the field of trauma studies, theirs is precisely a desire to study the effects of trauma, to

\footnotetext{
${ }^{32}$ Place, Statement of Facts, 155.
} 
understand, interpret, and redeem sense, precisely at the site where sense has been eradicated. In this way institutional oppression in Tragodia extends out from the text and it is the exposure of such oppression that forms part of the institutional critique in Place's act of reframing.

Affect then has been disabled by the law. The legal discourse denies a relationship between affectivity and rationality in the narratives, offering only a site for the latter. Interestingly, there are references to the victims' posttraumatic conditions in a number of the statements:

The nurse practitioner who examined Sara described her as placid and cooperative. The woods lamp scan was negative for bodily fluids; the nurse collected vaginal, cervical, anal, external genital, and breast swabs. Sara described the assault and her assailant, and said she was numb. There were ligature marks on Sara's wrists, and an abrasion on her knee; her hymen and vagina were bruised, consistent with blunt force pressure. There were fresh abrasions on her anal area, consistent with friction. These injuries were not consistent with consensual sex. There was no injury to the scalp, though this is not inconsistent with having one's hair pulled. (RT 3:1828-1851, 3:1855, 3:1874-1882, 3:1885-1896) Sara's demeanour was consistent with posttraumatic stress disorder. (RT 3:1910, 3:1917-1918) ${ }^{33}$

Told in the third person, Sara's narrative is obscured by the legal and medical reports of her trauma. The reference to post-traumatic stress disorder and Sara's 'demeanor' are slight in comparison to the lengthy, detailed, and explicit objective narrative of the physical trauma she has experienced, as forensic evidence in legal discourse is privileged over the narrative of the victims. It is the perception of the nurse who is given authority to assess Sara that takes precedence, and it is the nurse who states that Sara's exterior behavior was 'placid' and 'cooperative'. The nurse practitioner is given agency over the victim. Sara's own narrative is adumbrated into the fact of recollection: 'Sara described the assault and her assailant, and said that she was numb.' Whilst Sara's desensitized condition is reported, this condition of numbness is not expressed. Such objective renderings of Sara's own testimony repudiate affect, either in its presence or absence. Indeed such instances of linguistic obfuscation highlight the importance of the role of language, diction, and syntax in representing affect, when affect is, in Denise Riley's terms, attached to 'the expressive intentions of an individual

\footnotetext{
${ }^{33}$ Place, Statement of Facts, 123.
} 
speaker. ${ }^{34}$ There is, as Riley formulates in her recent body of work, another form of affect, 'the animated word's power' ${ }^{35}$ that is, to a certain extent, independent of an individual speaker. In this sense, a negative affect of indifference is at work in Place's practice. At times Sara is detached from her own body by the legal discourse, dispossessed by the lack of a possessive pronoun: 'the nurse collected vaginal, cervical, anal, external genital, and breast swabs'. Her body is objectified, mutilated through medical description, and Sara, divested of personhood, becomes a universal placeholder: 'There was no injury to the scalp, though this is not inconsistent with having one's hair pulled' (my italics). Within such a legal framing affectivity has been erased.

At other times, references to the victim's condition appear in footnotes. In the case that relates the gang rape of two women, Arianna and Miranda, the footnotes reveal that Arianna's narrative is almost entirely absent from the statement. As a gloss to a particularly traumatic part of the statement that tells of multiple sexual assaults on Arianna, a footnote reads: 'Arianna could not relate a specific sequence of events after this: she could not say what happened or how many times. (RT 4:1834, 4:1841, 4:2126, 4:2126-2127) ${ }^{36}$. Here Place's pure appropriation, which leaves the clerk's notes and footnotes in the post-text, reveals the way in which Arianna is subordinated structurally within the institutional narrative and by the legal paratextual elements. ${ }^{37}$ In the annotation Arianna has linguistic agency, yet she remains narrated by the law, the auxiliary statement that concerns her is outside of the main text and enclosed by the numbered footnote and the clerk's notes in parentheses. In the linguistic constructions of the section of the text to which the note refers, apart from one statement where she has dual agency with Miranda ('Miranda and Arianna asked not to let them in'), Arianna is passive, relegated to an ancillary position within the statements in which the appellant or the suspects are active: 'Appellant withdrew from Arianna'; 'Suspect 1 got on to the bed with Arianna, had her masturbate him'; 'Suspect 3 and 4 went to the bed and fondled Arianna'; 'Suspect 1 returned to Arianna's bed'; 'Suspect 4 fondled Arianna for a moment $[. .$.$] had Arianna orally copulate him'; 'Arianna was always being orally penetrated$ by one while the other was vaginally penetrating her'; 'Appellant came to the bed and raped Arianna.' Arianna's posttraumatic state is referred to within the text:

Miranda did most of the talking to the police because Arianna was "in a really bad place" at the time. They walked back to the building, because the officers needed the women to go into the apartment. Arianna couldn't at first, so

\footnotetext{
${ }^{34}$ Denise Riley, Impersonal Passion: Language as Affect (Durham and London: Duke University Press, 2005), 5.

${ }^{35}$ Place, Statement of Facts, 123.

${ }^{36}$ Ibid., 203.

${ }^{37}$ Ibid.
} 
Miranda did. After being reassured of her safety, Arianna also went upstairs and showed the officers where the attack took place. None of the suspects were present, but Arianna saw appellant's picture on a dining table. Arianna was confused, and vomited. They were transported to the hospital and interviewed and examined. Arianna was not very cooperative at the hospital because she just wanted to go home. (RT 4:1882, 4:1891, 4:2103-2105, $4: 2161-2165)^{38}$

It is not entirely clear if the citation from the original statement that appears in the first sentence ("in a really bad place") is spoken by Miranda or Arianna. Either way, the idiomatic quotation here highlights the tension between framing and telling. It is not unreasonable to speculate that the language of Arianna's original testimony would have embodied affect, as the legal statement here refers to her confusion and her state of shock. The final sentence of the extract: 'Arianna was not very cooperative at the hospital because she just wanted to go home' is an instance of a certain linguistic traction found in many of the statements. In this statement the language of the law strains to contain the victim's narrative. The first clause 'Arianna was not very cooperative' subsumes Arianna into the statement of the figure of the law telling the facts. The second clause however struggles to contain Arianna's verbal testimony within Standard English. As an example of many instances of free indirect discourse in the statements, Arianna's voice breaks through in the word 'just'. It registers Arianna's anxiety and points to the absent affective speech acts that have been deformed and linguistically standardized. This moment of slippage can also be read as a poetic act. Place has not altered the legal statement, but as Moschovakis observes: 'Statement of Facts is not only conceptual poetry written by a writer-slash-appellate attorney. These are appellate briefs written - the old fashioned way - by a poet. ${ }^{39}$ Moschovakis's remark calls into question the origin of Place's poetic practice. Place's conceptual writing occurs in the act of appropriation yet her poetic practice may have indeed begun when she wrote the briefs. ${ }^{40}$

The effect of the investigation on Arianna also suggests a form of violence inflicted on the victim by the systematic examination imposed in criminal law. Leone Sandra Hankey, a feminist scholar and a member of the California bar, states that '[f]eminist legal scholars and criminologists document and analyze the phenomenon that raped women who report the crime often experience a "second assault" from the legal system that has supposedly been

\footnotetext{
${ }^{38}$ Place, Statement of Facts, 206.

${ }^{39}$ Moschovakis, 'Poetics of Guilt', 10.

${ }^{40}$ The documentation of Tye's juvenile language would be another instance of this practice.
} 
designed to help them. ${ }^{41}$ The note to the section cited above points to Arianna's memory loss, possibly due to trauma: 'Arianna testified that she did not recall exactly what she told police or hospital staff in terms of who did what to her how often. ${ }^{42}$ A later note reads: 'According to Wall, Arianna was extremely distraught and difficult to talk to; Miranda provided all the information about the assault. ${ }^{43}$ Richard Wall, the watch field supervisor narrates Arianna's condition; again her distress is relegated to the footnotes. Significantly, the statement also points to Arianna's transformation after the assault: 'Arianna "became a different person" after the attack. She went to counseling, sought medical treatment, and became isolated from friends and family. She could not be alone, but the only person she could be with was Miranda. She hated "her own people" and could not be around people speaking Spanish. (RT 4:1891-1894, 4:2161), ${ }^{44}$. The legal accounts cite the parts of the victims' narratives that do not contain affect. Affect would be present if the parts of Arianna's verbal statement that expressed anxiety were cited. Instead, the legal interpretation of her speech act omits affective words. As a consequence, the reader of the text is left only with supposition with regards to Arianna's affective discourse.

Through reframing, Place's allegorical work draws attention to the distortion of the victims' speech acts by the figures of the law who interpret those narratives. New narratives are created through interpretation in which the victims are reified into the objective language of the law. The result is that within Statement of Facts, the victims are unable to constitute themselves through their speech acts. Immobilized within the rigid constructions of Standard English, any affect apparent in the original narratives has been erased and thus subjectivity has been occluded. As such, in the literary document as a read narrative, the agency intrinsic to personhood is not possible because the subjects' speech acts have been deformed.

\section{Performing Indifference}

Performance is a major extra-textual feature of Place's allegorical work. In her seminal work, The Poetics of Indeterminacy: Rimbaud to Cage (1999), Perloff posits the Aristotelian constituent part of tragedy, opsis, or spectacle, to be a significant element of performance, in

\footnotetext{
${ }^{41}$ Leone Sandra Hankey, 'Women Write Patriarchal Wrongs: Narrative Resistance to Rape Culture' in Beyond Portia: Women, Law, and Literature in the United States, edited by Jacqueline St. Joan and Annette Benington McElhiney (Boston: Northeastern University Press, 1997), 204.

42 Place, Statement of Facts, 206.

43 Ibid., 207.

${ }^{44}$ Ibid., 206-7.
}

URL: http://mc.manuscriptcentral.com/rtpr Email: pboxallpeter@googlemail.co14 
that 'it establishes a unique relationship between artist and audience. ${ }^{, 45}$ The performative use of indifference is a critical component of Place's conceptual practice. Place stages apathy in her performances of Tragodia 1: Statement of Facts. Kenneth Goldsmith has remarked on the importance of the performative dimension of Place's work. 'When you hear Place read these words,' he states, 'you realize that the vile content of the work is just the tip of the iceberg. What happens to you, the listener, during the reading is what makes what she's doing so important. ${ }^{46}$ Her voice, soft, monotone, detached, unaffected by the violence of the content of the narratives, reifies the narratives of the victims theatrically in a manner that mirrors the codification of the victim's narratives within legal discourse. Within the discursive construction of the text, facts oppress the subjects being narrated, objectivity replaces subjectivity. Place does not alleviate this violence in her performances, she makes no attempt to reinstate the personhood of the narratives that has been erased in the institutional transmission from the victim's statement to legal statement. Her voice operates to homogenize both the victims' and appellants' testimonies. Bringing their narratives into the same voice illuminates the enforced imbrication of individual narrative with legal discourse and the consequent obscuring of personhood in legal discourse.

Through Place's lack of mediation between text and audience, the performance of Statement of Facts opens up a space of participation. ${ }^{47}$ Fitterman and Place suggest that conceptual writing 'might be best defined not by the strategies used but by the expectations of the readership or thinkership. ${ }^{48}$ The traumatic impact of the performance of the text on the audience resides in the lack of mediation and precipitates a question of ethics. 'If there is an ethics specific to appropriation', Fitterman and Place contend, 'it is enacted in the question of editing. Does the writer edit, for example, online language because it is offensive? Does the act of editing becomes another ethical problem?' Crucially, the writers ask, 'Does the failure to edit become collusion?' ${ }^{49}$ This is a central issue that arises when Place's work is understood as cultural critique. For if the act of reframing does not provide a structure through which elements of personhood can be known, then the conceptual text is partly complicit in the erasure of personhood inflicted by legal discourse.

At the level of performance, Place's poetic practice creates a field of relations that intentionally generates trauma. Goldsmith remarks on his experience of listening to Place

\footnotetext{
${ }^{45}$ Marjorie Perloff, The Poetics of Indeterminacy: Rimbaud to Cage (Northwestern University Press, 1999), 289.

${ }^{46}$ Kenneth Goldsmith, Uncreative Writing: Managing Language in the Digital Age (New York: Columbia University Press, 2011), 104.

${ }^{47}$ A number of Place's readings are available on the web, for instance the reading at Point Ephémère, Paris, 30.9.11. http://www.youtube.com/watch?v=u5V7gk8Totk

${ }^{48}$ Fitterman and Place, Notes on Conceptualisms, 10.

${ }^{49}$ Ibid., 41.
} 
read: 'Hers is a poetics of realism: one so real that it's almost too much to bear. ${ }^{50}$ The unendurable element of Place's performance experienced by Goldsmith is brought about by pure appropriation. Goldsmith remarks that Place's lengthy readings, forty-five minutes or more, begin after a while 'to feel like a Hollywood movie, replete with tragedy and redemption. ${ }^{51}$ Goldsmith's reading here is problematic, as his rendering of the action of the narratives as redemptive in the Hollywood sense implies catharsis. In the text and in Place's readings there is no remedial interpretation of the text by the poet. As such there is no catharsis, as the interpretative logic of the law has disabled affect. Rather, the members of the audience, in listening to the statements, experience trauma, as a result of their exposure to the unmediated material. Place's performance foils the theatrical parts of Tragodía in her refusal to interpret and mediate. This element of Place's conceptual practice embodies an ethics of appropriation that can be positioned as a recalcitrant gesture against the violence of interpretation imposed by the law.

Place's performance in this vein can be understood as a strategy of failure. Paralleling her failure to edit the material in the conceptual act of reframing, the theatrical dimension of Place's work is 'an assassination of mastery', a rejection of the figure of the poet as mediator. Place's performance accords to the text's status as a transcript (and the subject's status as transcribed):

12a. transcript is a work of failure: the prosody used refers to a failed system (politics) of a failed humanity. A failure on all fronts; one that cannot exist save in its constant manifestation of a constant absence - the citation without content, with partial content, with mutilated content. ${ }^{52}$

Statement of Facts can be thought of as the last of these manifestations, whereby the mutilation occurs in the pre-text. Within the space of the mutilated texts there is the constant manifestation of the absence of affect. For Fitterman and Place, the text's status as a transcript relates directly to "the word as wound [...] (the site of failure). ${ }^{53}$ Fitterman and Place argue that in contemporary allegorical writing, failure has the capacity to 'irrupt the work, violating it from within. ${ }^{54}$ Furthermore, they propose that 'this invites the reader to redress failure, hallucinate repair. ${ }^{55}$ Read within the context of these notes, it becomes apparent that Statement of Facts invites such a response but it is precisely the impossibility of the

${ }^{50}$ Goldsmith, Uncreative Writing, 107.

${ }^{51}$ Ibid., 105.

${ }^{52}$ Fitterman and Place, Notes on Conceptualisms, 54.

${ }^{53}$ Ibid., 55.

${ }^{54}$ Ibid., 25.

${ }^{55}$ Ibid., 25.

URL: http://mc.manuscriptcentral.com/rtpr Email: pboxallpeter@googlemail.co16 
hallucination of repair that situates the audience within the experience of the posttraumatic subject, an experience generated by the text yet, paradoxically, absent in the redacted narratives of the law. Place's strategy of pure appropriation runs counter to the redaction inherent to narratives that she appropriates. The intentional generation of trauma in the performance of Tragodía 1: Statement of Facts functions to recover the affect overwritten in the narratives by legal discourse. As a consequence, two modes of performativity emerge in Place's work. At the level of the legal text, performativity occurs, to use Judith Butler's formulation, 'as that reiterative power of discourse to produce the phenomena that it regulates and constrains. ${ }^{56}$ In their notes, Fitterman and Place cite Wystan Curnow: 'Curnow notes that conceptual writing invites its own performativity, a performativity that ... is an attempt to disembed the meaning "in the contingent and the contextual." ${ }^{57}$ This form of performativity occurs in the act of reframing and, concomitantly, in Place's performance. Arguably, by recontextualising the work from the courtroom to the public reading venue, the performative act of reframing parallels the allegorical structure of the conceptual text.

Performance creates a site of resistance within Place's conceptual writing. In the text of Statement of Facts, identity has been erased by the deformation of the victims' speech acts. Transformation for the narrated subjects is impossible, as the victims' personhood has been eclipsed and as a result, within the oppressive discursive construction, there is no site for the self, and, therefore no site for the becoming other of the self. In Tragodia contextual deformation has erased subjectivity in the victims' narratives. Place's conceptual writing can be understood as resistance at the level of performance, and at the level of the conceptual act of reframing. Place's performance creates a site of reception between text and audience that is also space of trauma. The members of the audience, as constituted subjects, are liable to deconstitution through trauma and the involuntary generation of affect procured by witnessing trauma. Thus through performance, Place's conceptual practice opens up a site of affectual resistance, denied to the victims of sexual assault within the original legal documents. The allegorical structure, the movement from pre-text to post-text, reframes the legal text in such a way that it enables the formation of alterity, it becomes something other as a work of literature yet the post-text remains identical to the pre-text in content. In this vein, Place's Tragodía brings to light a bipartite field of the resistance of the conceptual text. Performance opens up a site of resistance impossible within the text, and, in revealing this impossibility Place's practice critiques the oppression of the victim's discourse and the reification of the subject within the ideological language of the law. The victims' narratives

\footnotetext{
${ }^{56}$ Judith Butler, Bodies that Matter: On the Discursive Limits of Sex (London: Routledge, 2011), xii.

${ }^{57}$ Fitterman and Place, Notes on Conceptualisms, 21. Curnow's paper was presented at the Conceptual Writing Conference held at the University of Arizona Poetry Centre in 2008.
} 
have been decontextualized and deformed. The act of pure appropriation can be understood as an act of decontextualisation but one through which the narratives remain intact. Reframing becomes an ethical gesture, a paratextual pathway to metamorphosis, positioned against the linguistic deformation that takes place in the legal narratives. The move from the cultural conditions in the pre-text to new narrative conditions in the post-text is a repositioning that, in its refusal to interpret, creates a site of contextual resistance and a new textual field of meaning-making.

URL: http://mc.manuscriptcentral.com/rtpr Email: pboxallpeter@googlemail.co18 